\title{
Absolute Stereostructures of Cell-adhesion Inhibitors, Peribysins A, E, F and G, Produced by a Sea Hare-derived Periconia sp.
}

\author{
Takeshi Yamada, Mitsunobu Doi, Atsuko Miura, Waka Harada, Mika Hiramura, \\ Katsuhiko Minoura, Reiko Tanaka, Atsushi Numata
}

Received: December 6, 2004 / Accepted: February 24, 2005

(C) Japan Antibiotics Research Association

\begin{abstract}
Peribysins $\mathrm{E} \sim \mathrm{G}(\mathbf{1} \sim \mathbf{3})$ have been isolated from a strain of Periconia byssoides originally separated from the sea hare Aplysia kurodai. Their absolute stereostructures have been elucidated on the basis of spectroscopic analyses using 1D and 2D NMR techniques and some chemical transformations. In addition, the absolute configuration of peribysin A (4), previously undetermined, has been established by conversion to $\mathbf{2}$ and 3. All these metabolites inhibited the adhesion of humanleukemia HL-60 cells to HUVEC.
\end{abstract}

Keywords fungus, peribysins, cell-adhesion inhibitor, Periconia sp., sea hare

\section{Introduction}

Based on the fact that some of the bioactive materials isolated from marine animals have been produced by bacteria, we have focused our attention on new antitumor materials from microorganisms separated from marine organisms [1 3]. As part of this study, we have previously isolated the cell-adhesion inhibitors, macrosphelides $\mathrm{E} \sim \mathrm{I}$, $\mathrm{L}[4,5]$ and peribysins A (4) D [6], from a strain of Periconia byssoides OUPS-N133 originally separated from the sea hare Aplysia kurodai. All of these compounds except for macrosphelide I inhibited the adhesion of human-leukemia HL-60 cells to human-umbilical-vein endothelial cells (HUVEC) more potently than herbimycin A $[7,8]$. Further investigation of the metabolites from this

T. Yamada (Corresponding author), M. Doi, A. Miura, W. Harada, M. Hiramura, K. Minoura, R. Tanaka, A. Numata: fungal strain has now led to the isolation of additional new anti-adhesion compounds designated peribysins $\mathrm{E} \sim \mathrm{G}$ (1 3) (Fig. 1). We describe herein the absolute stereostructures of peribysins $E \sim G(\mathbf{1} \sim \mathbf{3})$ and $A(4)$ (Fig. 1). The relative configuration of peribysin $\mathrm{A}$ has been briefly reported in a preliminary form [6] in addition to their inhibition of cell adhesion.

\section{Results and Discussion}

The fungal strain was cultured at $27^{\circ} \mathrm{C}$ for 4 weeks in a medium containing malt extract $1 \%$, glucose $1 \%$ and peptone $0.05 \%$ in artificial seawater adjusted to $\mathrm{pH} 7.5$, as reported previously $[4 \sim 6]$. The AcOEt extract of the

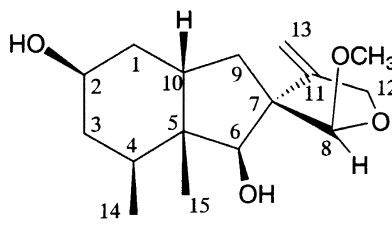

1

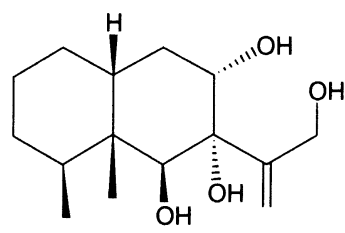

3

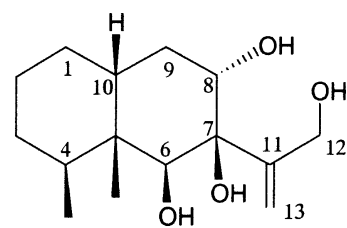

2<smiles>C=C(CO)C12OC1[C@@]1(C)[C@@H](C)CCC[C@H]1C[C@H]2O</smiles>

4
Fig. 1 Structures of peribysins $E(\mathbf{1}), F(2), G(3)$ and $A(4)$.

Osaka University of Pharmaceutical Sciences, 4-20-1, Nasahara, Takatsuki, Osaka 569-1094, Japan, E-mail: yamada@gly.oups.ac.jp 
Table 1 Physico-chemical properties of peribysin E $\sim(\mathbf{1} \sim \mathbf{3})$

\begin{tabular}{|c|c|c|c|}
\hline & 1 & 2 & 3 \\
\hline Appearance & Pale yellow oil & Pale yellow oil & Colorless needles (hexane $-\mathrm{CH}_{2} \mathrm{Cl}_{2}$ ) \\
\hline$[\alpha]_{D}^{22}$ & -262.2 (c $0.11, \mathrm{EtOH})$ & -21.5 ( с $0.10, \mathrm{EtOH})$ & -1.3 (c 0.10, EtOH) \\
\hline $\mathrm{Mp}\left({ }^{\circ} \mathrm{C}\right)$ & & & $187 \sim 189$ \\
\hline HREIMS Found: & $282.1827(\mathrm{M})^{+}$ & $270.1730(\mathrm{M})^{+}$ & $270.1730(\mathrm{M})^{+}$ \\
\hline Calcd: & 282.1831 (for $\mathrm{C}_{16} \mathrm{H}_{26} \mathrm{O}_{4}$ ) & 270.1724 (for $\mathrm{C}_{15} \mathrm{H}_{26} \mathrm{O}_{4}$ ) & 270.1724 (for $\mathrm{C}_{15} \mathrm{H}_{26} \mathrm{O}_{4}$ ) \\
\hline Molecular formula & $\mathrm{C}_{16} \mathrm{H}_{26} \mathrm{O}_{4}$ & $\mathrm{C}_{15} \mathrm{H}_{26} \mathrm{O}_{4}$ & $\mathrm{C}_{15} \mathrm{H}_{26} \mathrm{O}_{4}$ \\
\hline$U V \lambda_{\max }(\mathrm{EtOH}) \mathrm{nm}(\log \varepsilon)$ & 208 (3.79), 261 (2.97), 311 (2.64) & $205(3.41)$ & $205(2.25)$ \\
\hline $\mathrm{IR} v_{\max }$ (neat) $\mathrm{cm}^{-1}$ & 3415,1664 & $3387,1639,1595$ & $3372,1629,1593$ \\
\hline TLC Rf ${ }^{a}$ & 0.40 & 0.16 & 0.21 \\
\hline $\begin{array}{ll}\text { Solubility } & \text { soluble } \\
& \text { insoluble }\end{array}$ & $\begin{array}{l}\text { DMSO, } \mathrm{CH}_{2} \mathrm{Cl}_{2}, \mathrm{MeOH} \text {, acetone } \\
\mathrm{H}_{2} \mathrm{O}\end{array}$ & $\begin{array}{l}\text { DMSO, } \mathrm{MeOH} \text {, acetone } \\
\mathrm{CH}_{2} \mathrm{Cl}_{2}, \mathrm{H}_{2} \mathrm{O}\end{array}$ & $\begin{array}{l}\text { DMSO, } \mathrm{MeOH} \text {, acetone } \\
\mathrm{CH}_{2} \mathrm{Cl}_{2}, \mathrm{H}_{2} \mathrm{O}\end{array}$ \\
\hline
\end{tabular}

a Silica gel $\left(10 \% \mathrm{MeOH}\right.$ in $\left.\mathrm{CH}_{2} \mathrm{Cl}_{2}\right)$.

Table 2 NMR spectral data of peribysin $\mathrm{E}(\mathbf{1})$ in $\mathrm{CDCl}_{3}$

\begin{tabular}{|c|c|c|c|c|c|c|}
\hline Position & $\delta_{\mathrm{H}}{ }^{a}$ & $\mathrm{~J} / \mathrm{Hz}$ & ${ }^{1} \mathrm{H}-{ }^{1} \mathrm{H}$ COSY & NOE & $\delta_{\mathrm{C}}$ & $\mathrm{HMBC}(\mathrm{C})^{b}$ \\
\hline $1 \alpha$ & 1.94 dddd & $12.8(1 \beta), 4.8(2), 2.0(10), 1.8(3 \alpha)$ & $1 \beta, 2,10$ & $1 \beta, 2$ & $34.2(t)$ & 3,5 \\
\hline$\beta$ & $1.52 \mathrm{ddd}$ & $12.8(1 \alpha), 10.8(2), 5.3(10)$ & $1 \alpha, 2,10$ & $1 \alpha, 3 \beta, 10,15$ & & $2,5,9$ \\
\hline 2 & 3.92 dddd & $11.8(3 \beta), 10.8(1 b), 4.8(1 \alpha), 3.2(3 \alpha)$ & $1 \alpha, 1 \beta, 3 \alpha, 3 \beta$ & $1 \alpha, 3 \alpha, 4,9 \alpha$ & $67.1(d)$ & \\
\hline $3 \alpha$ & 1.71 dddd & $11.8(3 \beta), 4.0(4), 3.2(2), 1.8(1 \alpha)$ & $2,3 \beta, 4$ & $2,3 \beta, 4,14$ & $40.0(\mathrm{t})$ & \\
\hline$\beta$ & $1.27 q$ & $11.8(2,3 \alpha, 4)$ & $2,3 \alpha, 4$ & $1 \beta, 3 \alpha, 14,15$ & & $1,2,4$ \\
\hline 4 & $1.57 \mathrm{dqd}$ & $11.8(3 \beta), 7.2(14), 4.0(3 \alpha)$ & $3 \alpha, 3 \beta, 14$ & $2,3 \alpha, 6,9 \alpha, 14$ & $35.4(d)$ & \\
\hline 5 & & & & & 45.9 (s) & \\
\hline 6 & $3.56 \mathrm{~s}$ & & & $4,9 \alpha, 12 \alpha, 13 \mathrm{~A}, 14$ & $88.6(d)$ & $4,8,10,11$ \\
\hline 7 & & & & & $60.8(\mathrm{~s})$ & \\
\hline 8 & $5.09 \mathrm{~s}$ & & & $10,8-\mathrm{OCH}_{3}$ & $105.5(d)$ & $6,11,12,8-\mathrm{OCH}_{3}$ \\
\hline $9 \alpha$ & $1.76 \mathrm{t}$ & $13.8(9 \beta, 10)$ & $9 b, 10$ & $1,4,6,9 \beta, 13 \mathrm{~A}$ & $32.9(\mathrm{t})$ & $1,5,7,8,11$ \\
\hline$\beta$ & $1.89 \mathrm{dd}$ & $13.8(9 \alpha), 6.2(10)$ & $9 \alpha, 10$ & $9 \alpha, 10$ & & $5,6,7,8$ \\
\hline 10 & $2.01 \mathrm{~m}$ & & $1 \alpha, 1 \beta, 9 \mathrm{a}, 9 \beta$ & $1 \beta, 8,9 \beta, 15$ & $45.8(d)$ & $1,2,4,5$ \\
\hline 11 & & & & & 152.6 (s) & \\
\hline $12 \alpha$ & $4.49 \mathrm{dt}$ & $12.8(12 \beta), 2.2(13 \mathrm{~A}, 13 \mathrm{~B})$ & $12 \mathrm{~b}, 13 \mathrm{~A}, 13 \mathrm{~B}$ & $6,12 \beta$ & $68.9(\mathrm{t})$ & 11 \\
\hline$\beta$ & $4.40 \mathrm{dt}$ & $12.8(12 \alpha), 2.2(13 \mathrm{~A}, 13 \mathrm{~B})$ & $12 \alpha, 13 \mathrm{~A}, 13 \mathrm{~B}$ & $12 \alpha, 8-\mathrm{OCH}_{3}$ & & \\
\hline $13 \mathrm{~A}$ & $4.95 t$ & $2.2(12 \alpha, 12 b)$ & $12 \alpha, 12 \beta$ & $6,9 \alpha, 13 \mathrm{~B}$ & $103.1(\mathrm{t})$ & 7,12 \\
\hline B & $4.99 t$ & $2.2(12 \alpha, 12 \beta)$ & $12 \alpha, 12 \beta$ & $13 \mathrm{~A}$ & & 7,12 \\
\hline 14 & $0.86 d$ & $7.2(4)$ & 4 & $3 \alpha, 3 \beta, 4,6,15$ & $16.1(q)$ & $3,4,5$ \\
\hline 15 & $0.93 \mathrm{~s}$ & & & $1 \beta, 2 \beta, 10,14$ & $14.4(q)$ & $4,5,6,10$ \\
\hline $6-\mathrm{OH}$ & n.d. & & & & & \\
\hline $8-\mathrm{OCH}_{3}$ & $3.38 \mathrm{~s}$ & & & $8,12 \beta$ & $55.1(q)$ & 8 \\
\hline
\end{tabular}

${ }^{a}{ }^{1} \mathrm{H}$ chemical shift values $\left(\delta \mathrm{ppm}\right.$ from $\left.\mathrm{SiMe}_{4}\right)$ followed by multiplicity and then the coupling constants $(\mathrm{J} / \mathrm{Hz})$. Figures in parentheses indicate the proton coupling with that position. ${ }^{b}$ Long range ${ }^{1} \mathrm{H}-{ }^{13} \mathrm{C}$ correlations from $\mathrm{H}$ to $\mathrm{C}$ observed in the $\mathrm{HMBC}$ experiment.

culture filtrate was purified by fractionation employing a combination of Sephadex LH-20 and silica gel column chromatographies and reversed phase HPLC to afford peribysins $\mathrm{E} \sim \mathrm{G}(\mathbf{1} \sim \mathbf{3})$. The physico-chemical properties of these compounds are summarized in Table 1.

Peribysin E (1) had the molecular formula $\mathrm{C}_{16} \mathrm{H}_{26} \mathrm{O}_{4}$ established by the $[\mathrm{M}]^{+}$peak of $\mathbf{1}$ in HREIMS. The IR spectrum exhibited bands at 3415 and $1664 \mathrm{~cm}^{-1}$, 


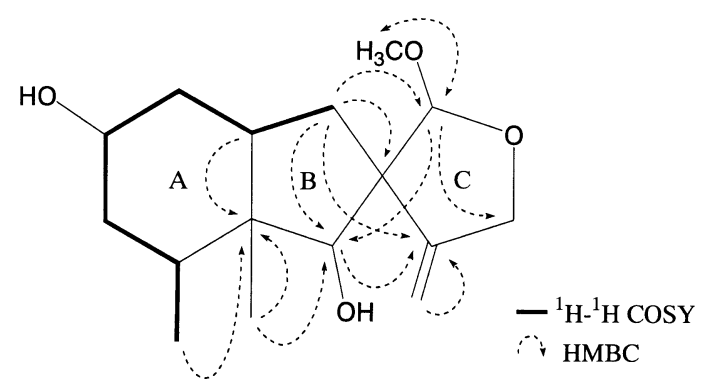

Fig. 2 Selected ${ }^{1} \mathrm{H}-{ }^{1} \mathrm{H}$ COSY and $\mathrm{HMBC}$ correlations in peribysin E (1).

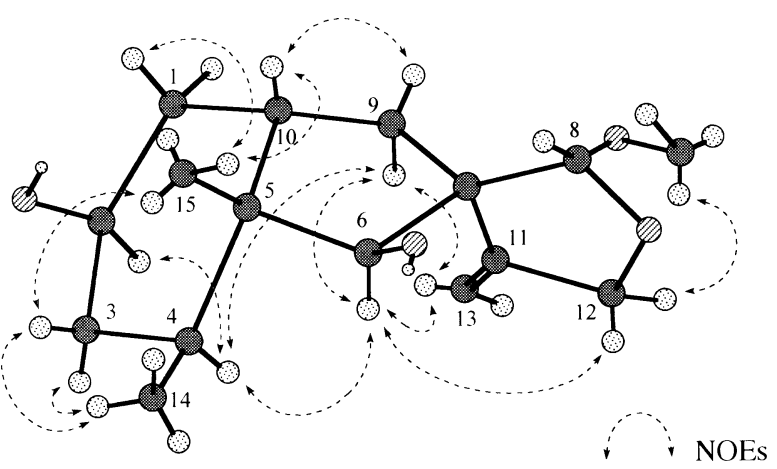

Fig. 3 Observed NOEs for peribysin E (1).

characteristic of an alcohol and a double bond. A close inspection of the ${ }^{1} \mathrm{H}$ and ${ }^{13} \mathrm{C}$ NMR spectra of $\mathbf{1}$ (Table 2) by DEPT and ${ }^{1} \mathrm{H}-{ }^{13} \mathrm{C}$ COSY experiments revealed the presence of one vinylidene (C-11 and C-13), one secondary methyl (C-14), one tertiary methyl (C-15), four $s p^{3}$ hybridized methylenes (C-1, C-3, C-9 and C-12) including one oxygen-bearing carbon (C-12), five $s p^{3}$-methines $(\mathrm{C}-2$, C-4, C-6, C-8 and C-10) including three oxymethines (C-2, C-6 and C-8), two quarternary $s p^{3}$-carbons (C-5 and C-7) and one methoxyl group (8-OMe). The ${ }^{1} \mathrm{H}-{ }^{1} \mathrm{H}$ COSY analysis of $\mathbf{1}$ led to a partial structural unit as shown by bold-faced lines in Fig. 2, which was supported by HMBC correlations (Table 2). The connection of this unit and the remaining functional groups was determined on the basis of the key HMBC correlations summarized in Fig. 2. The acetylation of $\mathbf{1}$ gave diacetate $\mathbf{5}$, and protone signals for 2$\mathrm{H}$ and 6-H were downfield-shifted from $\delta_{\mathrm{H}} 3.92$ and $\delta_{\mathrm{H}}$ 3.56 to $\delta_{\mathrm{H}} 5.01$ and $\delta_{\mathrm{H}} 4.87$, respectively. This fact implied that the hydroxyl groups exist at C-2 and C-6. Based on the above evidence, the planar structure of $\mathbf{1}$ was elucidated.

The stereochemistry of $\mathbf{1}$ was deduced from NOESY experiments (Table 2, Fig. 3). NOE correlations from 15-H to $1 \beta-\mathrm{H}$ and $3 \beta-\mathrm{H}$ implied that the $\mathrm{A}$ ring exists in a chair conformation with the 5 -methyl group, $1 \beta-\mathrm{H}$ and $3 \beta-\mathrm{H}$ in

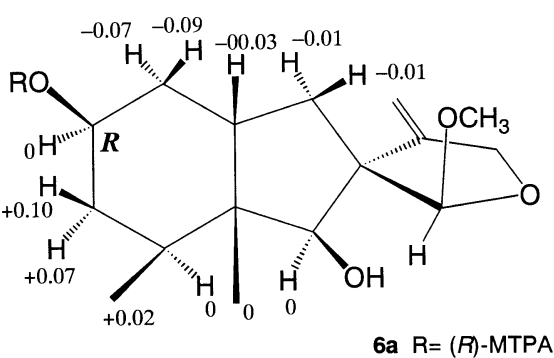

6b $R=(S)-M T P A$

Fig. $4{ }^{1} \mathrm{H}$ chemical-shift differences $\left(\Delta \delta=\delta_{S}-\delta_{R}\right)$ between the $(R)$ - and (S)-MTPA esters $\mathbf{6 a}$ and $\mathbf{6 b}$ of peribysin E (1).

coaxial arrangements. NOEs from $15-\mathrm{H}$ to $10-\mathrm{H}$, and from $14-\mathrm{H}$ to $3 \beta-\mathrm{H}$ suggested that 5 -methyl group is oriented cis to both $10-\mathrm{H}$ and 4-methyl group in equatorial arrangements. In addition to NOEs from $6-\mathrm{H}$ to $4-\mathrm{H}, 9 \alpha-\mathrm{H}$ and $13 \mathrm{~A}-\mathrm{H}, \mathrm{NOE}$ between $10-\mathrm{H}$ and $9 \beta-\mathrm{H}$ was implied that 6- $\mathrm{H}$ is oriented cis to both $4-\mathrm{H}$ and $\mathrm{C}-7-\mathrm{C}-11$ bond, and therefore $\mathrm{C}-7-\mathrm{C}-8$ bond is oriented cis to both $10-\mathrm{H}$ and $9 \beta-\mathrm{H}$. Furthermore, NOE correlations $(12 \beta-\mathrm{H} / 8-\mathrm{OMe}$ and $12 \alpha-\mathrm{H} / 6-\mathrm{H})$ showed that $8-\mathrm{H}$ is cis to $\mathrm{C}-7-\mathrm{C}-6$ bond. Based on the evidence summarized above, the relative stereostructure $\mathbf{1}$ for peribysin E was elucidated as depicted in Fig. 3.

The modified Mosher method [9] was applied to determine the absolute configuration of peribysin E (1). The ${ }^{1} \mathrm{H}$ chemical-shift differences between the $(R)$ - and $(S)$ MTPA esters $\mathbf{6 a}$ and $\mathbf{6 b}$ of compound $\mathbf{1}$ are shown in Fig. 4. The result suggested that a $2 R$ configuration, and hence allowed assignment of absolute stereostructure 1 as $2 R, 4 S$, $5 R, 6 S, 7 S, 8 R, 10 R$ configuration for peribysin $\mathrm{E}$.

Peribysin F (2) had the molecular formula $\mathrm{C}_{15} \mathrm{H}_{26} \mathrm{O}_{4}$ established by HREIMS. Close inspection of the ${ }^{1} \mathrm{H}$ and ${ }^{13} \mathrm{C}$ NMR spectra of 2 (Table 3) by DEPT and ${ }^{1} \mathrm{H}-{ }^{13} \mathrm{C}$ COSY experiments revealed the presence of one vinylidene $(\mathrm{C}-11$ and $\mathrm{C}-13)$, one secondary methyl (C-14), one tertiary methyl (C-15), five $s p^{3}$-hybridized methylenes (C-1, C-2, $\mathrm{C}-3, \mathrm{C}-9$ and $\mathrm{C}-12)$ including one hydroxymethyl (C-12), four $s p^{3}$-methines (C-4, C-6, C-8 and C-10) including two oxymethines (C-6 and C-8), two $s p^{3}$ quaternary carbons (C5 and C-7) including one oxygen-bearing carbon (C-7). Analysis of The ${ }^{1} \mathrm{H}-{ }^{1} \mathrm{H}$ COSY and HMBC (from H-6 to C5, C-7, C-8, C-10 and C-11, from $\mathrm{H}-13$ to $\mathrm{C}-7$ and $\mathrm{C}-12$, and from $\mathrm{H}-12 \mathrm{~B}$ to $\mathrm{C}-7, \mathrm{C}-11$ and $\mathrm{C}-13$ ) correlations led to the planar structure for $\mathbf{2}$. Furthermore, acetylation of $\mathbf{2}$ gave the triacetate 7 , and proton signals for $6-\mathrm{H}, 8-\mathrm{H}$ and $12-\mathrm{H}$ were downfield-shifted to $\delta_{\mathrm{H}} 5.62, \delta_{\mathrm{H}} 5.14$ and $\delta_{\mathrm{H}}$ 4.72 , respectively. This fact implied that the tertiary hydroxyl groups exist at C-6, C-8 and C-12. In addition the 
Table 3 NMR spectral data of peribysins $F(\mathbf{2})$ and $G(\mathbf{3})$ in $\mathrm{MeOH}-d_{4}$

\begin{tabular}{|c|c|c|c|c|}
\hline \multirow{2}{*}{ Position } & \multicolumn{2}{|c|}{2} & \multicolumn{2}{|c|}{3} \\
\hline & $\delta_{\mathrm{H}}{ }^{a}$ & $\delta_{\mathrm{C}}$ & $\delta_{\mathrm{H}}{ }^{a}$ & $\delta_{\mathrm{C}}$ \\
\hline 1 & $1.62 \mathrm{~m}$ & $29.3(t)$ & $\begin{array}{ll}\alpha & 1.32 \mathrm{dt} \\
\beta & 1.77 \mathrm{tt}\end{array}$ & $28.5(t)$ \\
\hline 2 & $1.44 \mathrm{~m}$ & $22.0(\mathrm{t})$ & $\begin{array}{l}\alpha 1.58 \mathrm{~m} \\
\beta 1.44 \mathrm{dtt}\end{array}$ & $22.2(t)$ \\
\hline 3 & $\begin{array}{l}\alpha 1.48 \mathrm{~m} \\
\beta 1.28 \mathrm{~m}\end{array}$ & $31.7(t)$ & $1.32 \mathrm{~m}$ & $32.2(\mathrm{t})$ \\
\hline 4 & $2.05 \mathrm{~m}$ & 33.3 (d) & $2.80 \mathrm{dqd}$ & 30.7 (d) \\
\hline 5 & & 42.5 (s) & & 42.1 (s) \\
\hline 6 & $4.01 \mathrm{~s}$ & 74.7 (d) & $3.60 \mathrm{~s}$ & 79.0 (d) \\
\hline 7 & & 80.5 (s) & & 80.9 (s) \\
\hline 8 & $3.87 \mathrm{dd}$ & 76.2 (d) & $4.17 \mathrm{dd}$ & 70.2 (d) \\
\hline 9 & $\begin{array}{l}\alpha 1.97 \mathrm{~m} \\
\beta 1.77 \mathrm{br} d\end{array}$ & $33.8(\mathrm{t})$ & $\begin{array}{l}2.25 q \\
1.32 m\end{array}$ & $32.5(t)$ \\
\hline 10 & $1.90 \mathrm{~m}$ & 38.3 (d) & $1.80 \mathrm{dq}$ & 37.6 (d) \\
\hline 11 & & 151.7 (s) & & 154.7 (s) \\
\hline 12 & $\begin{array}{l}\text { A } 4.22 \mathrm{~d} \\
\text { B } 4.31 \mathrm{~d}\end{array}$ & $64.7(\mathrm{t})$ & $4.29 \mathrm{~s}$ & $65.1(\mathrm{t})$ \\
\hline 13 & $\begin{array}{l}\text { A } 5.43 \mathrm{~s} \\
\text { B } 5.63 \mathrm{~s}\end{array}$ & $116.8(t)$ & $\begin{array}{l}5.37 \mathrm{~s} \\
5.45 \mathrm{~s}\end{array}$ & $115.8(t)$ \\
\hline 14 & $0.83 d$ & $17.1(q)$ & $0.81 \mathrm{~d}$ & $17.3(q)$ \\
\hline 15 & $1.04 \mathrm{~s}$ & $18.5(q)$ & $0.92 \mathrm{~s}$ & 18.1 (q) \\
\hline
\end{tabular}

${ }^{a}$ As in Table 1.

presence of a hydroxy group at the remaining oxygenated carbon (C-7) was deduced from its carbon chemical-shift $\left(\delta_{\mathrm{C}} 80.53\right)$ and the molecular formula of 2 . In NOESY experiment, NOEs $(15-\mathrm{H}$ to $1 \beta-\mathrm{H}, 3 \beta-\mathrm{H}, 10-\mathrm{H}$ and $14-\mathrm{H})$ observed in A ring of $\mathbf{2}$ were the same as those of peribysin E (1), implying that the A ring exists in a chair conformation. In addition, NOEs $(10-\mathrm{H}$ to $8-\mathrm{H}, 9 \alpha-\mathrm{H}$ to $4-$ $\mathrm{H}, 6-\mathrm{H}$ to $4-\mathrm{H}$ and $121-\mathrm{H}$, and $13 \mathrm{~B}-\mathrm{H}$ to $4-\mathrm{H})$ implied that the $\mathrm{B}$ ring exists in a chair conformation with the 8- $\mathrm{H}, 10-$ $\mathrm{H}$ and 6-hydroxy group in coaxial arrangements and with 5-methyl group and 7-hydroxy group in equatorial arrangements. Based on the above evidence, the relative stereostructure 2 for peribysin $F$ was elucidated. The absolute configuration of $\mathbf{2}$ is described later.

Peribysin G (3) had the same molecular formula as $\mathbf{2}$ based on HREIMS. The general features of the ${ }^{1} \mathrm{H}$ and ${ }^{13} \mathrm{C}$ NMR spectra (Table 3 ) closely resembled those of $\mathbf{2}$ except that the proton signal for $4-\mathrm{H}\left(\delta_{\mathrm{H}} 2.05\right)$ and $6-\mathrm{H}\left(\delta_{\mathrm{H}} 4.01\right)$, and the carbon signal for C- $6\left(\delta_{\mathrm{C}} 74.71\right)$ and C- $8\left(\delta_{\mathrm{C}}\right.$ $76.15)$ in 3 revealed a chemical shift difference relative to those of 2. The ${ }^{1} \mathrm{H}-{ }^{1} \mathrm{H}$ COSY and HMBC (from 6-H to C-5,

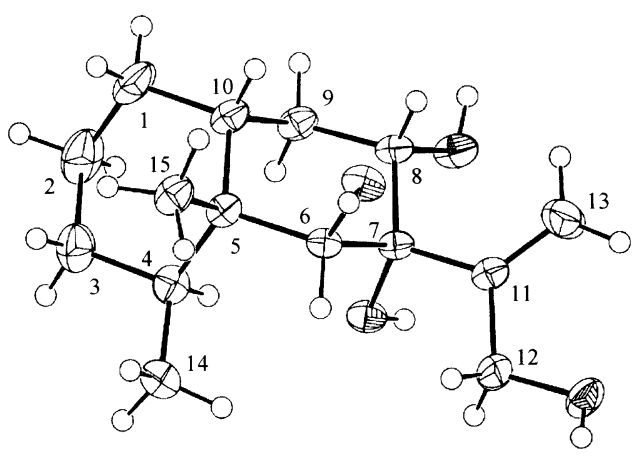

Fig. 5 X-Ray crystal structure for peribysin G (3).

C-7, C-8, C-10 and C-11, from $13-\mathrm{H}$ to $\mathrm{C}-7$ and $\mathrm{C}-12$, and from $12-\mathrm{H}$ to $\mathrm{C}-7, \mathrm{C}-11$ and $\mathrm{C}-13$ ) correlations (Table 3) implied that peribysin $\mathrm{G}(3)$ has the same planar structure as 2. In NOESY experiment, NOEs $(15-\mathrm{H}$ to $1 \beta-\mathrm{H}, 3-\mathrm{H}$, $10-\mathrm{H}$ and 14-H) observed in A ring of 3 were the same as those of above peribysins, implying that the A ring exists in a twist-chair conformation with $1 \beta-\mathrm{H}, 3 \beta$-H and 5-methyl group in coaxial arrangements. In addition, NOEs (10-H to $8-\mathrm{H}, 9 \alpha-\mathrm{H}$ to $4-\mathrm{H}$, and $6-\mathrm{H}$ to $4-\mathrm{H}, 14-\mathrm{H}$ and $15-\mathrm{H})$ implied that the $\mathrm{B}$ ring exists in a chair conformation with the $8-\mathrm{H}$, $10-\mathrm{H}$ and 6-hydroxy group in coaxial arrangements and with 5-methyl group in equatorial arrangements. In addition, an X-ray crystal-structure analysis was carried out for a single crystal of $\mathbf{3}$ (obtained by recrystallization from hexane- $\mathrm{CH}_{2} \mathrm{Cl}_{2}$ ) (Fig. 5). Based on the above evidence, peribysin $\mathrm{G}(3)$ was found to be the C-7 stereoisomer of peribysin $F$ (2). The absolute configuration of 3 was elucidated by application of CD spectrum [10]. Bis- $p$ bromobenzoate $\mathbf{8}$ derived from peribysin $\mathrm{G}(\mathbf{3})$ exhibited positive first and negative second Cotton effect [ $253 \mathrm{~nm}(\Delta \varepsilon$ $+8.8)$ and $238 \mathrm{~nm}(\Delta \varepsilon-4.5)]$ in the CD spectrum. This evidence allowed assignment of the absolute configuration of $\mathbf{3}$ as shown in Fig. 5.

The relative stereostructure of peribysin A (4) has already been reported previously [6], but its absolute configuration has remained undecided. The modified Mosher method was not applied for determination of the absolute configuration of 4 , because the $8-\mathrm{OH}$, the secondary hydroxy group in 4 , had not been derivatized to an MTPA ester. Therefore peribysin A (4) was converted to peribysin $G(3)$, the absolute stereostructure of which had already been determined. The acid-catalyzed hydrosis of 4 gave both peribysin $G(3)$ and $F(2)$, however peribysin F (2) and G (3) were not artefacts because of the potent stability of $\mathbf{4}$ in various solvent. Based on this evidence, the absolute configuration of peribysin A (4) and F (2) were elucidated. 
Table 4 Inhibitory activities against cell adhesion of metabolites

\begin{tabular}{lll}
\hline \multicolumn{2}{c}{ Compound } & $\mathrm{IC}_{50}(\mu \mathrm{M})$ \\
\hline \multirow{2}{*}{ Peribysin } & $\mathrm{E}(\mathbf{1})$ & 11.5 \\
& $\mathrm{~F}(\mathbf{2})$ & 20.7 \\
& $\mathrm{G}(\mathbf{3})$ & 15.6 \\
Herbimycin A & (standard) & 38.0 \\
\hline
\end{tabular}

Peribysins $E \sim G(\mathbf{1} \sim \mathbf{3})$ were examined using herbimycin A $[7,8]$ as a standard sample in the adhesion assay system using HL-60 cells and HUVEC, according to a modification of the method reported by Miki and coworkers [11]. As shown in Table 4, all of these compounds inhibited the adhesion of HL-60 cell to HUVEC more potently than herbimycin A.

\section{Experimental}

\section{General}

UV spectra were recorded on a Shimadzu spectrophotometer and IR spectra on a Perkin Elmer FT-IR spectrometer 1720X. NMR spectra were recorded at $27^{\circ} \mathrm{C}$ on Varian UNITY INOVA-500 and MERCURY spectrometers with tetramethylsilane (TMS) as an internal reference. EIMS was determined using a Hitachi M-4000H mass spectrometer. ORD and CD spectra were recorded on a JASCO J-820 polarimeters. Liquid chromatography over silica gel (mesh 230 400) was performed at medium pressure. HPLC was run on a Waters ALC-200 instrument equipped with a differential refractometer (R 401) and Shim-pack PREP-ODS $(25 \mathrm{~cm} \times 20 \mathrm{~mm}$ i.d. $)$. Analytical TLC was performed on precoated Merck aluminum sheets (DC-Alufolien Kieselgel $60 \mathrm{~F}_{254}, 0.2 \mathrm{~mm}$ ) with the solvent system $\mathrm{CH}_{2} \mathrm{Cl}_{2}-\mathrm{MeOH}(19: 1)$, and compounds were viewed under UV lamp and sprayed with $10 \% \mathrm{H}_{2} \mathrm{SO}_{4}$ followed by heating.

\section{Culturing and Isolation of Metabolites}

A strain of Periconia byssoides OUPS-N133, separated from the sea hare Aplysia kurodai, was cultured at $27^{\circ} \mathrm{C}$ for four weeks in a liquid medium (90 liters) containing malt extract $1 \%$, glucose $1 \%$ and peptone $0.05 \%$ in artificial seawater adjusted to $\mathrm{pH}$ 7.5. As reported previously [4], the AcOEt extract $(5.7 \mathrm{~g})$ of the culture filtrate was successively chromatographed on Sephadex LH-20 $\left(\mathrm{CH}_{2} \mathrm{Cl}_{2}-\mathrm{MeOH}, 1: 1\right)$ and silica gel $\left(\mathrm{CH}_{2} \mathrm{Cl}_{2} / \mathrm{MeOH}\right)$. The $\mathrm{MeOH}-\mathrm{CH}_{2} \mathrm{Cl}_{2}(2: 98)$ eluate $(172.6 \mathrm{mg})$ from silica gel column chromatography was purified by HPLC using $\mathrm{MeOH}-\mathrm{H}_{2} \mathrm{O}(7: 3)$ as the eluent to afford $\mathbf{1}(17.8 \mathrm{mg}$, $0.31 \%)$. The $\mathrm{MeOH}-\mathrm{CH}_{2} \mathrm{Cl}_{2}(5: 95)$ eluate $(223.8 \mathrm{mg})$ from silica gel column chromatography was purified by HPLC using $\mathrm{MeOH}-\mathrm{H}_{2} \mathrm{O}(6: 4)$ as the eluent to afford 2 (12.7 mg, 0.22\%), 3 (8.8 mg, 0.15\%).

\section{Acetylation of Peribysin E (1)}

To a solution of $\mathbf{1}(2.2 \mathrm{mg})$ in pyridine $(1.0 \mathrm{ml})$ was added $\mathrm{Ac}_{2} \mathrm{O}(1.0 \mathrm{ml})$, and the reaction mixture was left at room temperature overnight. The mixture was concentrated to dryness under reduced pressure, and residue was purified by HPLC using $\mathrm{MeOH}-\mathrm{H}_{2} \mathrm{O}(9: 1)$ as the eluent to afford diacetate $5(1.8 \mathrm{mg})$ as a pale yellow oil.

Diacetate 5: $[\alpha]_{\mathrm{D}}+35.0\left(c 0.069\right.$, EtOH); IR $v_{\max }$ (neat) $\mathrm{cm}^{-1} 1738$ (ester), 1602, $1586(\mathrm{C}=\mathrm{C})$; EIMS $m / z 366\left(\mathrm{M}^{+}\right.$, 1.0\%); HREIMS $m / z$ for $\mathrm{C}_{20} \mathrm{H}_{30} \mathrm{O}_{6}\left(\mathrm{M}^{+}\right)$, Calcd: 366.0966 ; Found: $366.0948 ;{ }^{1} \mathrm{H}$ NMR $\delta$ ppm $\left(\mathrm{CDCl}_{3}\right): 0.84(3 \mathrm{H}, \mathrm{d}$, $J=7.2 \mathrm{~Hz}, 14-\mathrm{H}), 0.86(3 \mathrm{H}, \mathrm{s}, 15-\mathrm{H}), 1.29(1 \mathrm{H}, \mathrm{q}, J=11.8$ $\mathrm{Hz}, 3 \beta-\mathrm{H}), 1.63(1 \mathrm{H}$, ddd, $J=12.7,10.8,5.1 \mathrm{~Hz}, 1 \beta-\mathrm{H})$, $1.75(1 \mathrm{H}$, dqd, $J=11.8,7.2,3.8 \mathrm{~Hz}, 4-\mathrm{H}), 1.80(1 \mathrm{H}$, dddd, $J=11.8,3.8,3.0,1.9 \mathrm{~Hz}, 3 \alpha-\mathrm{H}), 1.89(1 \mathrm{H}, \mathrm{t}, 13.5,9 \alpha-\mathrm{H})$, $1.94(1 \mathrm{H}$, dddd, $J=12.7,4.8,2.0,1.9 \mathrm{~Hz}, 1 \alpha-\mathrm{H}), 2.03(3 \mathrm{H}$, $\left.\mathrm{s}, \mathrm{COOCH}_{3}\right), 2.04(1 \mathrm{H}, \mathrm{m}, 9 \beta-\mathrm{H}), 2.06(1 \mathrm{H}, \mathrm{m}, 10-\mathrm{H}), 2.07$ $\left(3 \mathrm{H}, \mathrm{s}, \mathrm{COOCH}_{3}\right), 3.35\left(3 \mathrm{H}, \mathrm{s}, 8-\mathrm{OCH}_{3}\right), 4.28(1 \mathrm{H}, \mathrm{dt}$, $J=12.8,2.3 \mathrm{~Hz}, 12 \beta-\mathrm{H}), 4.39(1 \mathrm{H}, \mathrm{dt}, J=12.8,2.3 \mathrm{~Hz}$, $12 \alpha-\mathrm{H}), 4.87(1 \mathrm{H}, \mathrm{s}, 6-\mathrm{H}), 4.93(1 \mathrm{H}, \mathrm{s}, 8-\mathrm{H}), 5.00(1 \mathrm{H}, \mathrm{t}$, $J=2.3 \mathrm{~Hz}, 13 \mathrm{~A}-\mathrm{H}), 5.01(1 \mathrm{H}, \mathrm{m}, 2-\mathrm{H}), 5.03(1 \mathrm{H}, \mathrm{t}, J=2.3$ $\mathrm{Hz}, 13 \mathrm{~B}-\mathrm{H})$.

\section{Formation of the $(R)$ - and $(S)$-MTPA Esters 6a and $6 \mathrm{~b}$ from Peribysin E (1)}

(R)-MTPA $(2.0 \mathrm{mg})$, dicyclohexylcarbodiimide (DCC) $(2.0 \mathrm{mg})$ and $4-($ dimethylamino)-pyridine (DMAP) $(1.0 \mathrm{mg})$ were added to a $\mathrm{CH}_{2} \mathrm{Cl}_{2}$ solution $(0.2 \mathrm{ml})$ of peribysin $\mathrm{E}(\mathbf{1})$ $(0.6 \mathrm{mg})$, and the reaction mixture was left at room temperature for 3 hours. The solvent was evaporated off under reduced pressure, and the residue was purified by HPLC using $\mathrm{MeOH}-\mathrm{H}_{2} \mathrm{O}(9: 1)$ as the eluent to afford $(R)$ MTPA ester 6a $(0.7 \mathrm{mg})$ as an amorphous powder. The same reaction with $1(0.7 \mathrm{mg})$ using $(S)$-MTPA $(2.2 \mathrm{mg})$ gave ester $\mathbf{6 b}(0.8 \mathrm{mg})$.

Ester 6a: EIMS $m / z 498\left(\mathrm{M}^{+}, 3.0 \%\right)$; HREIMS $\mathrm{m} / \mathrm{z}$ for $\mathrm{C}_{26} \mathrm{H}_{33} \mathrm{~F}_{3} \mathrm{O}_{6}\left(\mathrm{M}^{+}\right)$, Calcd: 498.2228; Found: 498.2224; ${ }^{1} \mathrm{H}$ NMR $\delta$ ppm $\left(\mathrm{CDCl}_{3}\right): 0.86(3 \mathrm{H}, \mathrm{d}, J=6.9 \mathrm{~Hz}, 14-\mathrm{H}), 0.92$ $(3 \mathrm{H}, \mathrm{s}, 15-\mathrm{H}), 1.37(1 \mathrm{H}, \mathrm{q}, J=12.6 \mathrm{~Hz}, 3 \beta-\mathrm{H}), 1.65(1 \mathrm{H}, \mathrm{m}$, 4-H), $1.76(1 \mathrm{H}, \mathrm{m}, 1 \beta-\mathrm{H}), 1.78(1 \mathrm{H}, \mathrm{m}, 3 \alpha-\mathrm{H}), 1.81(1 \mathrm{H}, \mathrm{t}$, $J=13.5 \mathrm{~Hz}, 9 \alpha-\mathrm{H}), 1.95(1 \mathrm{H}, \mathrm{dd}, J=13.5,5.5 \mathrm{~Hz}, 9 \beta-\mathrm{H})$, $2.01(1 \mathrm{H}, \mathrm{m}, 1 \alpha-\mathrm{H}), 2.03(1 \mathrm{H}, \mathrm{m}, 10-\mathrm{H}), 2.17(1 \mathrm{H}, \mathrm{br}$ s, 6$\mathrm{OH}), 3.38$ (3H, s, 8-OMe), $3.56(3 \mathrm{H}, \mathrm{s}, \mathrm{OMe}), 3.57(1 \mathrm{H}, \mathrm{s}$, 6-H), $4.41(1 \mathrm{H}, \mathrm{dt}, J=12.8,2.2 \mathrm{~Hz}, 12 \beta-\mathrm{H}), 4.49(1 \mathrm{H}, \mathrm{dt}$, 
$J=12.8,2.2 \mathrm{~Hz}, 12 \alpha-\mathrm{H}), 4.99(1 \mathrm{H}, \mathrm{t}, J=2.2 \mathrm{~Hz}, 13 \mathrm{~A}-\mathrm{H})$, $5.01(1 \mathrm{H}, \mathrm{t}, J=2.2 \mathrm{~Hz}, 13 \mathrm{~B}-\mathrm{H}), 5.06(1 \mathrm{H}, \mathrm{s}, 8-\mathrm{H}), 5.27(1 \mathrm{H}$, dddd, $J=12.5,10.5,5.0,3.1 \mathrm{~Hz}, 2-\mathrm{H}), 7.41$ (3H, m, Ar.H) and $7.53(2 \mathrm{H}, \mathrm{m}, \mathrm{Ar} . \mathrm{H})$.

Ester 6b: EIMS $m / z 498\left(\mathrm{M}^{+}, 2.2 \%\right)$; HREIMS $m / z$ for $\mathrm{C}_{26} \mathrm{H}_{33} \mathrm{~F}_{3} \mathrm{O}_{6}\left(\mathrm{M}^{+}\right)$, Calcd: 498.2228; Found: 498.2224; ${ }^{1} \mathrm{H}$ NMR $\delta$ ppm $\left(\mathrm{CDCl}_{3}\right): 0.88(3 \mathrm{H}, \mathrm{d}, J=6.9 \mathrm{~Hz}, 14-\mathrm{H}), 0.92$ $(3 \mathrm{H}, \mathrm{s}, 15-\mathrm{H}), 1.47(1 \mathrm{H}, \mathrm{q}, J=12.4 \mathrm{~Hz}, 3 \beta-\mathrm{H}), 1.65(1 \mathrm{H}, \mathrm{m}$, 4-H), $1.67(1 \mathrm{H}, \mathrm{m}, 1 \beta-\mathrm{H}), 1.80(1 \mathrm{H}, \mathrm{t}, J=13.5 \mathrm{~Hz}, 9 \alpha-\mathrm{H})$, $1.85(1 \mathrm{H}, \mathrm{m}, 3 \alpha-\mathrm{H}), 1.94(1 \mathrm{H}, \mathrm{m}, 1 \alpha-\mathrm{H}), 1.94(1 \mathrm{H}, \mathrm{m}, 9 \beta-$ H), $2.00(1 \mathrm{H}, \mathrm{m}, 10-\mathrm{H}), 2.17(1 \mathrm{H}$, br s, 6-OH), $3.37(3 \mathrm{H}, \mathrm{s}$, 8-OMe), 3.57 (3H, s, OMe), $3.57(1 \mathrm{H}, \mathrm{s}, 6-\mathrm{H}), 4.41(1 \mathrm{H}$, $\mathrm{dt}, J=12.8,2.2 \mathrm{~Hz}, 12 \beta-\mathrm{H}), 4.49(1 \mathrm{H}, \mathrm{dt}, J=12.8,2.2 \mathrm{~Hz}$, $12 \alpha-\mathrm{H}), 4.98(1 \mathrm{H}, \mathrm{t}, J=2.2 \mathrm{~Hz}, 13 \mathrm{~A}-\mathrm{H}), 5.01(1 \mathrm{H}, \mathrm{t}, J=2.2$ $\mathrm{Hz}, 13 \mathrm{~B}-\mathrm{H}), 5.06(1 \mathrm{H}, \mathrm{s}, 8-\mathrm{H}), 5.27(1 \mathrm{H}, \mathrm{dddd}, J=12.4$, 10.6, 5.0, 3.2 Hz, 2-H), $7.41(3 \mathrm{H}, \mathrm{m}, \mathrm{Ar} . \mathrm{H})$ and $7.53(2 \mathrm{H}$, $\mathrm{m}, \mathrm{Ar} . \mathrm{H})$.

\section{Acetylation of Peribysin F (4)}

Using the same procedure as above with compound $\mathbf{1}$, a solution of $4(1.5 \mathrm{mg})$ in pyridine $(1.0 \mathrm{ml})$ was treated with $\mathrm{Ac}_{2} \mathrm{O}(1.0 \mathrm{ml})$ and purified by HPLC $\left[\mathrm{MeOH}-\mathrm{H}_{2} \mathrm{O}(9: 1)\right]$ to afford triacetate $7(1.3 \mathrm{mg})$ as a pale yellow oil.

Triacetate 7: $[\alpha]_{\mathrm{D}}+9.8(c 0.079, \mathrm{EtOH})$; IR $v_{\max }$ (neat) $\mathrm{cm}^{-1} 3485(\mathrm{OH}), 1743$ (ester), 1653, $1595(\mathrm{C}=\mathrm{C})$; EIMS $m / z 396\left(\mathrm{M}^{+}, 0.3 \%\right)$; HREIMS $m / z$ for $\mathrm{C}_{21} \mathrm{H}_{32} \mathrm{O}_{7}\left(\mathrm{M}^{+}\right)$, Calcd: 396.1677; Found: 396.1658; ${ }^{1} \mathrm{H}$ NMR $\delta$ ppm $\left(\mathrm{CDCl}_{3}\right): 0.86(3 \mathrm{H}, \mathrm{d}, J=7.1 \mathrm{~Hz}, 14-\mathrm{H}), 1.04(3 \mathrm{H}, \mathrm{s}, 15-\mathrm{H})$, $1.28(1 \mathrm{H}, \mathrm{m}, 3 \beta-\mathrm{H}), 1.43(2 \mathrm{H}, \mathrm{m}, 2-\mathrm{H}), 1.44(1 \mathrm{H}, \mathrm{m}, 3 \alpha-$ H), $1.58(2 \mathrm{H}, \mathrm{m}, 9-\mathrm{H}), 1.58(2 \mathrm{H}, \mathrm{m}, 1-\mathrm{H}), 1.74(1 \mathrm{H}, \mathrm{br} \mathrm{s}, 4-$ $\mathrm{H}), 1.92\left(1 \mathrm{H}\right.$, br s, 10-H), $2.02\left(3 \mathrm{H}, \mathrm{s}, \mathrm{COOCH}_{3}\right), 2.08(3 \mathrm{H}$, $\left.\mathrm{s}, \mathrm{COOCH}_{3}\right), 2.08\left(3 \mathrm{H}, \mathrm{s}, \mathrm{COOCH}_{3}\right), 2.80(1 \mathrm{H}, \mathrm{s}, 7-\mathrm{OH})$, $4.72(2 \mathrm{H}, \mathrm{s}, 12-\mathrm{H}), 5.14(\mathrm{H}$, br s, $8-\mathrm{H}), 5.37(1 \mathrm{H}, \mathrm{s}, 13 \mathrm{~A}-$ H), $5.58(1 \mathrm{H}, \mathrm{s}, 13 \mathrm{~B}-\mathrm{H}), 5.62(1 \mathrm{H}, \mathrm{s}, 6-\mathrm{H})$.

\section{X-Ray Crystallography of Peribysin G (3)}

Peribysin $\mathrm{G}$ (3) was crystallized from hexane - $\mathrm{CH}_{2} \mathrm{Cl}_{2}$ solution by the vapor diffusion method. Crystal data: $\mathrm{C}_{15} \mathrm{H}_{26} \mathrm{O}_{4}, M_{\mathrm{r}}=270.36$, monoclinic, $P 2_{1}, a=7.960$ (2) $\AA$, $b=8.605$ (2) $\AA, c=10.955(3) \AA, b=106.855(4)^{\circ}, V=718.1$ (3) $\AA^{3}, Z=2, F(000)=296, \mu(\mathrm{Mo}-\mathrm{K} \alpha)=0.089 \mathrm{~mm}^{-1}$. Data collection was performed by a Bruker smart APEX using Mo-K $\alpha$ radiation. Total 6292 reflections were collected until $\theta=27.10 \AA$, in which 1685 reflections were observed $(I>2 \sigma(I))$. The crystal structure was solved by the direct method using SHELXS-97 [12]. The structure was refined by the full matrix least-squares method on $F$ using SHELXL-97 [12]. In the structure refinements, nonhydrogen atoms were refined with anisotropic temperature factors. Hydrogen atoms were calculated on the geometrically ideal positions by the 'ride on' method, and were included in the calculation of structure factors with isotropic temperature factors. In the final stage, $R=0.0440$, $w R=0.1224$ and $S=1.198$ were obtained.

\section{Formation of Bis-p-bromobenzoate 8 from Peribysin $\mathbf{G}$}

(3)

To a solution of $\mathbf{3}(0.78 \mathrm{mg})$ in pyridine $(0.1 \mathrm{ml})$ was added $p$-bromobenzoylchloride $(1.6 \mathrm{mg})$, and the reaction mixture was left at room temperature for 1 hour. The mixture was concentrated to dryness under reduced pressure, and residue was purified by $\mathrm{HPLC}$ using $\mathrm{MeOH}-\mathrm{H}_{2} \mathrm{O}(9: 1)$ as the eluent to afford $8(0.69 \mathrm{mg})$ as-pale yellow oil.

Bis-p-bromobenzoate 8: EIMS $m / z 636\left(\mathrm{M}^{+}, 6.7 \%\right)$; HREIMS $\mathrm{m} / \mathrm{z}$ for $\mathrm{C}_{29} \mathrm{H}_{32} \mathrm{Br}_{2} \mathrm{O}_{6}\left(\mathrm{M}^{+}\right)$, Calcd: 636.0536; Found: $636.0533 ;{ }^{1} \mathrm{H}$ NMR $\delta$ ppm $\left(\mathrm{CDCl}_{3}\right): 0.86(3 \mathrm{H}, \mathrm{d}$, $J=6.6 \mathrm{~Hz}, 14-\mathrm{H}), 1.05(3 \mathrm{H}, \mathrm{s}, 15-\mathrm{H}), 1.26(1 \mathrm{H}, \mathrm{m}, 3 \beta-\mathrm{H})$, $1.34(1 \mathrm{H}, \mathrm{m}, 3 \alpha-\mathrm{H}), 1.37(1 \mathrm{H}, \mathrm{m}, 1 \alpha-\mathrm{H}), 1.49(2 \mathrm{H}, \mathrm{m}, 2-$ H), $1.65(1 \mathrm{H}$, ddd, $J=12.8,4.8,3.9 \mathrm{~Hz}, 9 \beta-\mathrm{H}), 1.75(1 \mathrm{H}$, m, $1 \beta-\mathrm{H}), 2.07(1 \mathrm{H}, \mathrm{m}, 10-\mathrm{H}), 2.30(1 \mathrm{H}, \mathrm{d}, J=3.2 \mathrm{~Hz}, 6-$ $\mathrm{OH}), 2.40(1 \mathrm{H}, \mathrm{q}, J=12.8 \mathrm{~Hz}, 9 \alpha-\mathrm{H}), 2.77(1 \mathrm{H}, \mathrm{d}, J=3.2$ $\mathrm{Hz}, 6-\mathrm{H}), 4.93(1 \mathrm{H}, \mathrm{d}, J=13.3 \mathrm{~Hz}, 12 \mathrm{~A}-\mathrm{H}), 5.01(1 \mathrm{H}, \mathrm{d}$, $J=13.3 \mathrm{~Hz}, 12 \mathrm{~B}-\mathrm{H}), 5.36(1 \mathrm{H}, \mathrm{s}, 13 \mathrm{~A}-\mathrm{H}), 5.37(1 \mathrm{H}, \mathrm{s}, 13 \mathrm{~B}-$ H), $5.72(1 \mathrm{H}, \mathrm{dd}, J=12.8,4.8 \mathrm{~Hz}, 8-\mathrm{H}), 7.54(2 \mathrm{H}, \mathrm{d}, J=8.8$ $\mathrm{Hz}, \operatorname{Ar} . \mathrm{H}), 7.56(2 \mathrm{H}, \mathrm{d}, J=8.8 \mathrm{~Hz}, \operatorname{Ar} . \mathrm{H}), 7.79(2 \mathrm{H}, \mathrm{d}$, $J=8.8 \mathrm{~Hz}, \mathrm{Ar} . \mathrm{H}), 7.84$ (2H, d, $J=8.8 \mathrm{~Hz}, \mathrm{Ar} . \mathrm{H})$.

\section{Formation of Peribysin F (2) and G (3) from Peribysin A (4)}

To a solution of $4(6.7 \mathrm{mg})$ in $\mathrm{MeOH}(0.1 \mathrm{ml})$ was added $\mathrm{H}_{2} \mathrm{O}(2.0 \mathrm{ml})$ and $\mathrm{c}-\mathrm{HCl}$ (1 drop), and the reaction mixture was left at room temperature for 1 hour. The mixture was concentrated to dryness under reduced pressure, and residue was purified by $\mathrm{HPLC}$ using $\mathrm{MeOH}-\mathrm{H}_{2} \mathrm{O}(6: 4)$ as the eluent to afford $2(1.77 \mathrm{mg})$ and $3(2.56 \mathrm{mg})$, the spectral date of which were identical with the natural products.

\section{Cell Adhesion Assay}

This assay was carried out according to a modification of the Miki's method using 3-(4,5-di-methyl-2-thiazolyl)-2,5diphenyl-2H-tetrazolium bromide (MTT)-labeled cells [9] HUVEC (DIA-IATRON Co., Ltd.) were cultured until confluent in a 96-well plate in medium 199 (Gibco) containing $10 \%$ fetal calf serum (FCS, Gibco) and washed with phosphate buffered saline (PBS, DIA-IATRON Co., Ltd.) containing $20 \%$ FCS. The HUVEC were stimulated with a solution of lipopolysaccharides (LPS, Sigma) in RPMI 1640 medium (Gibco) containing 10\% FCS for 4 hours in the presence of various concentrations of macrosphelides, and then MTT-labeled HL-60 cells were added and incubated for 40 minutes at $37^{\circ} \mathrm{C}$ in $5 \% \mathrm{CO}_{2}$. 
Unbound cells were gently washed out with PBS containing 10\% FCS, and DMSO was added to lyse the adherent HL-60 cells. Absorbance at $540 \mathrm{~nm}$ was measured using a microplate reader (Model 450, BIO-RAD).

Acknowledgements We thank Dr. K. Kawai (Fuso Pharmaceutical Industries, Ltd.) for his helpful advice on cell adhesion assay.

\section{References}

1. Amagata $T$, Doi M, Ohta $T$, Minoura $K$, Numata A. Absolute stereostructures of novel cytotoxic metabolites, gymnastatins $\mathrm{A} \sim \mathrm{E}$, from a Gymnascella species separated from a Halichodria sponge. J Chem Soc Perkin Trans 1: 3585-3599 (1998), and references cited therein.

2. Amagata T, Doi M, Tohgo M, Minoura K, Numata A. Dankasterone, a new class of cytotoxic steroid produced by a Gymnascella species from a marine sponge. Chem Commun 1321-1322 (1999)

3. Iwamoto C, Yamada T, Ito Y, Minoura K, Numata A. Cytotoxic cytochalasans from a Penicillium species separated from a marine alga. Tetrahedron 57: 2997-3004 (2001)

4. Yamada T, Iritani M, Doi M, Minoura K, Ito T, Numata A. Absolute stereostructures of cell adhesion inhibitors, macrosphelides $\mathrm{C}, \mathrm{E} \sim \mathrm{G}$ and $\mathrm{I}$, produced by a Periconia species separated from an Aplysia sea hare. J Chem Soc Perkin Trans 1: 3046-3053 (2001)
5. Yamada T, Iritani M, Minoura K, Numata A. Absolute stereostructures of cell adhesion inhibitors, macrosphelide $\mathrm{H}$ and L, from Periconia byssoides OUPS-N133. J Antibiot 55: 147-154 (2002)

6. Yamada $\mathrm{T}$, Iritani $\mathrm{M}$, Minoura $\mathrm{K}$, Kawai $\mathrm{K}$, Numata $\mathrm{A}$. Peribysin $\mathrm{A} \sim \mathrm{D}$, potent cell-adhesion inhibitors from a sea hare-derived culture of Periconia species. J Org Biomol Chem 2131-2135 (2004)

7. Weber C, Negrescu E, Erl W, Piersch A, Frankenberger M, ZiegleR-Heitbrock HWL, Siess W, Weber PC. Inhibitors of protein tyrosine kinase suppress TNF-stimulated induction of endothelial cell adhesion molecules. J Immunol 155: 445-451 (1995)

8. May MJ, Wheeler-Jones CPD, Pearson JD. Effects of protein tyrosine kinase inhibitors on cytokine-induced adhesion molecule expression by human umbilical vein endothelial cells. Br J Pharmacol 118: 1761-1771 (1996)

9. Miki I, Ishihara N, Otoshi M, Kase H. Simple colorimetric cell-cell adhesion assay using MTT-stained leukemia cells. J Immunol Methods 164: 255-261 (1993)

10. Harada H, Saito A, Ono H, Murai S, Li HY, Gawronski J, Gawronski K, Sugioka T, Uda H. A CD method for determination of the absolute stereochemistry of acyclic glycols. 2. Application of the CD exciton chirality method to acyclic 1,2 dibenzoates systems. Enantiomer 1: 119 (1996)

11. Ohtani I, Kusumi T, Kashman Y, Kakizawa H. High-field FT NMR application of Mosher's method. The absolute configurations of marine terpenoids. J Am Chem Soc 113: 4092-4096 (1991)

12. Sheldrick GM. SHELXS-97 and SHELXL-97, University of Gotingen, Germany 